\title{
Change of fluorescence in ambers according to artificial aging Jongseo Park ${ }^{\star}$ and Yujin Lim \\ Research Division of Restoration Technology, National Research Institute of \\ Cultural Heritage, 132 Munji-ro, Yuseong-gu, Daejeon 305-380, Korea \\ (Received February 2, 2012; Revised April 13, 2012; Accepted April 13, 2012)
}

\section{인공열화에 따른 호박(amber)의 형광특성 변화 박종서 ${ }^{\star}$ 임유진 \\ 국립문화재연구소 복원기술연구실 \\ (2012. 2. 2. 접수, 2012. 4. 13. 수정, 2012. 4. 13. 승인)}

\begin{abstract}
Ambers are composed of polymer molecules which contain aromatic moieties such as benzene, naphthalene, phenanthrene and anthracene. They emit fluorescence when irradiated with ultraviolet light, which was used for confirming an amber. The fluorescence of amber, however, tends to decrease as the surface of amber is weathered with light, heat, oxygen for a long time. In this study, the reliability of confirming amber with its fluorescence by measuring the changes of fluorescence after artificial aging. Aging factors were UV light $(\lambda=340 \mathrm{~nm})$, oxygen with heat $\left(100 \%, 90{ }^{\circ} \mathrm{C}\right)$ and heat $\left(90{ }^{\circ} \mathrm{C}\right)$ and aging time was for $5,15,30$ and 60 days, respectively. In the excitation and emission spectra of amber, the intensity decreased and the maximal wavelength was shifted to longer wavelength with artificial aging time. Especially, there was a drastic decrease in the intensity of spectra to $1.7 \%$ of initial value after 60 days aging under oxygen with heat. Only in Colombian amber there showed an increase of fluorescence intensity for a certain aging time, which could be explained by the production of aromatic ring in the presence of light and heat. Conclusively, the fluorescence can be lessened by the natural weathering with light, heat and oxygen and it is not accurate to recognize amber just with UV irradiation method.

요 약: 호박은 benzene, naphthalene, phenanthrene, anthracene과 같은 aromatic ring을 포함하는 화합물로 구성되어 있어 자외선 조사 시 형광을 나타낸다. 하지만, 공기, 열, 빛 등에 노출되어 자연적인 열화과정 을 거치면서 표면이 풍화되고 그에 따라 형광특성이 약해지는 경향이 있다. 본 연구에서는 인공적인 열 화를 실시하고 형광의 변화를 관찰하여 형광현상을 이용한 호박 확인방법의 유효성을 평가하고자 하였 다. 열화인자는 자외선 $(\lambda=340 \mathrm{~nm})$, 산소 $\left(100 \%, 90{ }^{\circ} \mathrm{C}\right)$, 열 $\left(90{ }^{\circ} \mathrm{C}\right)$ 이고, 열화기간은 $5,15,30,60$ 일로 하 여 열화를 실시하였다. 자외선 조사에 따른 형광스펙트럼에서는 세 가지 인자에 대해 시간이 경과하면서 형광의 세기가 감소하고 형광의 파장은 장파장으로 이동하였다. 특히, 산소 분위기에서 열화된 호박에서 는 60 일이 경과한 후 형광의 세기가 초기값의 $1.7 \%$ 로 급격하게 감소하였다. 다만, Colombian호박의 경 우 열화 후 일정시간까지 형광의 세기가 증가하고 있어 열, UV등의 인자가 오히려 aromatic ring을 생성
\end{abstract}

Corresponding author

Phone : +82-(0)42-860-9342 Fax : +82-(0)42-861-5168

E-mail : jongseo71@korea.kr 
하면서 호박화를 촉진하는 것으로 판단된다. 결론적으로, 열, 빛, 산소 등이 존재하는 자연 상태에서 호 박의 형광이 약화됨을 확인할 수 있었고, 호박유물 조사에서 호박의 확인을 형광 관찰에만 의존하기는 어려운 것으로 판단된다.

Key words: amber, fluorescence, artificial aging, heat, oxygen, light

\section{1. 서 론}

호박은 나무에서 나오는 삼출물이 수백만 년 동안 땅 속에 묻혀 화석화된 것으로서 Baltic, Colombian, Dominican, Fushun 등 생성된 장소에 따라 다양하게 분류되고 있다. ${ }^{1}$ 옛날부터 광택, 희소성 등 보석으로서 의 특징을 가지고 있어 장식품, 공예품 등에 사용되어 왔으며, 다양한 경로를 통하여 전 세계에서 거래가 이 루어졌다. 우리나라에서 호박의 산지는 보고되지 않고 있으나 고분, 사지, 석탑 등의 발굴 과정에서 발견되 고 있으며, 조선시대에 사용된 호박장식품은 상당수가 전세되어 오고 있다.

호박은 화학적으로 communic acid, abietic acid, pimaric acid 등 diterpenoid 계열에 속하는 물질들의 radical polymerization에 의해 형성된다. ${ }^{2}$ 고분자화된 이들 분자들은 화학구조에서 benzene, naphthalene, perylene과 같은 방향족 고리(aromatic ring)를 포함하는 분자가 있어 자외선을 조사할 때 형광을 나타낸다. ${ }^{3,4}$ 이 특성은 발굴과정에서 출토되는 유리, 옥수, 마노, 산호, 비취 등 다양한 유물들로부터 호박재질의 유물 을 구분하는데 사용되고 있다. 한편, 호박을 유리, 옥 수 등 유사 색상 물질과 구별하는 방법은 가열법, 감 촉비교법, 풍화문관찰법, 자외선검사법, 소금물이용법, 정전기이용법 등이 있으나, 이 중 파괴, 접촉, 변형이 없는 풍화문관찰법, 자외선검사법과 같은 비파괴 방법 이 호박유물 조사에 적합하다. 풍화문관찰법은 호박을 공예품 등으로 가공 후 시간이 경과하면서 생성된 표 면의 풍화무늬를 관찰하는 방법인데, 호박만의 독특한 풍화무늬에 대한 정보는 정리된 것이 없어 국내에서
는 활용되지 않고 있다. 또한, 오염된 환경에서 출토 된 경우 오염물에 의해 복잡한 풍화 양상을 보이므로 활용의 한계 또한 존재한다. 자외선 검사법은 호박에 자외선을 조사할 때 형광을 나타내는 성질을 이용하 여 호박을 식별하는 방법으로 풍화가 없는 표면에서 는 강한 형광을 나타내지만 풍화가 진행된 후에는 형 광이 약해지는 경향이 있다. 따라서, 풍화된 호박에 대한 적용성에 대한 평가가 필요하다.

본 연구에서는 열화에 따른 호박의 형광특성의 변 화를 관찰하기 위하여 열, 산소, $\mathrm{UV}$ 를 열화인자로 택 해 60일 동안 열화를 시킨 후 형광변화를 관찰하여 열화에 따른 형광특성의 변화와 함께 이에 따른 자외 선 검사법의 유효성을 검토하고자 하였다.

\section{2. 실 험}

\section{1. 시약 및 재료}

실험에 사용한 호박은 Baltic, Colombian, Dominican, Fushun 호박이었으며, 호박판매업자로부터 원석을 구 매하여 사용하였다. 구입한 시료목록을 Table 1에 나 타내었다. 분석에 사용한 시료는 풍화의 영향을 배제 하기 위하여 원석을 절단한 후 드러난 내부를 사용하 였다. 형광측정과 열화실험이 가능하도록 호박 덩어리 를 막자사발에 갈아 가루형태로 사용하였다.

\section{2. 열화실험}

\subsubsection{UV에 의한 열화}

4종류의 산지별 호박 시료를 $40{ }^{\circ} \mathrm{C}$ 로 유지된 $\mathrm{UV}$ 조사 장치(UV2000 ATLAS, $\lambda=340 \mathrm{~nm}$ )에서 열화시켰

Table 1. Amber samples used in this study

\begin{tabular}{ccccc}
\hline \hline 구분 & Baltic(BA) & Colombian(CO) & Dominican(DO) & Fushun(FU) \\
\hline & & & & \\
사진 & & & & \\
\end{tabular}


다. 구역이 나눠진 Petri dish에 powder 형태의 시료를 얇게 깔고 다시 petri dish를 Tedlar bag $(1 \mathrm{~L})$ 에 넣었다. Tedlar bag에 진공을 걸어 주어 공기를 뺀 후 질소를 충전하여 외부로부터의 산소의 영향을 최대한 제거하 였다. 열화가 시작된 후 $5,15,30,60$ 일 단위로 호박 시료를 꺼내어 형광측정 실험을 실시하였다.

\subsection{2. 열에 의한 열화}

4종류의 산지별 호박시료를 $90{ }^{\circ} \mathrm{C}$ 의 항온항습조 (JEIO TECH TH-PE-100, Korea)에서 열화시켰다. 열 화기간 $(5,15,30,60$ 일 $)$ 별로 형광측정이 가능하도록 4개의 유리 vial(약 $2 \mathrm{~mL}$ )에 powder 형태의 시료를 담고 뚜껑을 닫지 않은 상태로 광구병 $(100 \mathrm{~mL})$ 에 vial 을 넣은 후 광구병의 뚜껑을 살짝 닫아 다시 Tedlar bag $(1 \mathrm{~L})$ 에 넣었다. Tedlar bag에 진공을 걸어 주어 공기를 뺀 후 질소를 충전한 다음 광구병의 뚜껑을 단단히 닫아 외부로부터의 산소의 영향을 최대한 제 거하였다. 또한 빛의 영향을 제거하기 위해 항온항습 조 내부의 조명을 제거하였다. 이 때 항온항습조 내 부의 습도는 $5 \sim 8 \%$ 였다. 열화가 시작된 후 5,15 , 30,60 일 단위로 호박시료를 꺼내어 형광측정 실험 을 실시하였다.

\subsection{3. 열과 산소에 의한 열화}

상온에서 60 일 동안 산소에 의한 열화는 매우 미미 하여 형광변화를 관찰하기 어려웠다. 따라서 열이 가 해지는 환경에서 산소의 영향에 따른 호박시료의 변 화를 관찰하였다. 열화 조건은 열에 의한 열화 실험과 동일하다. 다만 Tedlar bag에서 공기를 뺀 후 질소 대 신 산소를 주입하여 산소조건을 구현하였다. 열화가 시작된 후 $5,15,30,60$ 일 단위로 호박시료를 꺼내어 형광측정 실험을 실시하였다.

\section{3. 형광 측정}

형광 측정은 $\mathrm{SCINCO} \mathrm{FS-2} \mathrm{(신코)} \mathrm{장비를} \mathrm{사용하였}$ 으며, 측정조건은 다음과 같이 설정하였다.

PMT voltage $=600 \mathrm{~V}$, Excitation slit $=5 \mathrm{~nm}$, Emission slit $=5 \mathrm{~nm}$, Integration time $=20 \mathrm{~ms}$, Response time $=0.02 \mathrm{~s}$

분말 시료를 고체형 셀 홀더에 장착시키고 장비를 충분히 예열시켰다. 우선 scan mode를 emission scan 으로 설정하고 최대의 excitation이 일어나는 emission 파장을 측정하였다. 측정한 emission 파장을 입력하고 scan mode를 excitation scan으로 설정하여 최대의 emission이 일어나는 excitation파장을 측정하였다. 측 정된 excitation 파장을 입력하고 위의 과정을 측정된 excitation, emission파장 값과 입력한 excitation, emission 파장 값이 일치될 때가지 반복하였다. 이 때 얻은 스 펙트럼을 각각 호박시료의 excitation spectrum과 emission spectrum으로 하였다.

\section{3. 결과 및 고찰}

\section{1. 열화 전 호박의 형광}

Table 2에 산지별 호박시료의 자외선 $(\lambda=365 \mathrm{~nm})$ 조 사에 따른 형광 사진을 나타냈으며, Fig. 1에 이들 시 료의 excitation 스펙트럼과 emission 스펙트럼을 나타 내었다. excitation 스펙트럼과 emission 스펙트럼 사이 의 거울상 대칭성과 다수 peak의 존재로부터 이들 스 펙트럼이 방향족 탄화수소에서 기인함을 알 수 있었 다. ${ }^{3}$ excitation 스펙트럼의 세기는 Dominican, Baltic, Fushun, Colombian순이었으며, emission스펙트럼의 세 기도 이 순서를 따랐다. 형광의 세기가 가교결합 (crosslinking)에 따른 방향성 정도(aromaticity)와 관련 있다는 점을 고려했을 때 Dominican과 Baltic이 시기 적으로 오래되었음을 알 수 있다. Colombian 호박은

Table 2. Photos of ambers under the natural light and the ultraviolet light $(\lambda=365 \mathrm{~nm})$

\begin{tabular}{|c|c|c|c|c|}
\hline 구분 & BA & $\mathrm{CO}$ & $\mathrm{DO}$ & $\mathrm{FU}$ \\
\hline 자연광 노출 & & & & \\
\hline 자외선 조사 & & & & \\
\hline
\end{tabular}




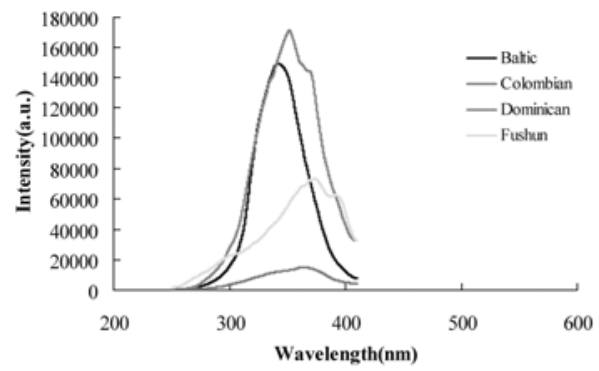

(a)

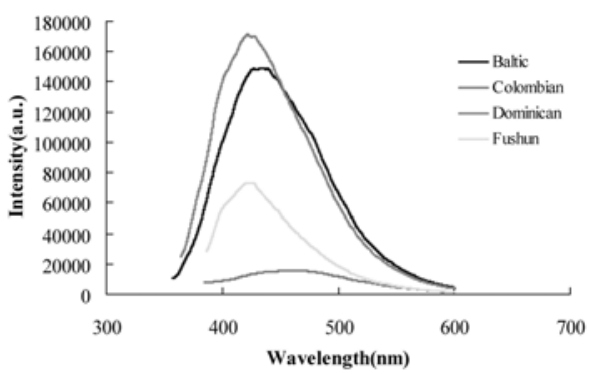

(b)

Fig. 1. Excitation (a) and emission (b) spectra of freshly exposed ambers with different origin.

Table 3. The wavelengths of maximum excitation and emission

\begin{tabular}{ccccc}
\hline \hline 구분 & $\mathrm{BA}$ & $\mathrm{CO}$ & $\mathrm{DO}$ & $\mathrm{FU}$ \\
\hline$\lambda_{\max }(\mathrm{ex})$ & 343 & 364 & 352 & 374 \\
$\lambda_{\max }(\mathrm{em})$ & 435 & 467 & 424 & 425 \\
\hline
\end{tabular}

흡수의 세기가 매우 약한데, 수지의 호박화가 덜 되어 방향성 정도(aromaticity)가 약하기 때문이다. 실제로 $365 \mathrm{~nm}$ 빛을 조사한 상태에서 형광을 관찰했을 때 Dominican과 Baltic에서 훨씬 밝은 빛의 형광이 나타 났다(Table 2). 형광 스펙트럼의 파장범위는 350 550 $\mathrm{nm}$ 로 노랑, 초록, 파랑, 남색에 해당하였다.

산지별 호박시료의 형광측정에서 최대의 excitation 과 emission이 나타나는 파장은 다음 표와 같다(Table 3). 형광 스펙트럼의 최대 파장을 형광을 나타내는 aromatic ring의 최대파장과 비교했을 때 naphthalene 보다 더 큰 분자에 해당하는 것으로 보인다.

Fushun, Dominican의 excitation 스펙트럼에서는 여 러 개의 peak이 겹치는 multiple peak structure를 보이 고 있는데, 형광을 나타내는 분자의 종류가 다양할 수 있음을 의미한다. 하지만, naphthalene, anthracene, perylene 등도 2 3개의 excitation peak를 가지고 있으 므로 열화에 따른 변화를 관찰해야 판단이 가능하다. 특히, Fushun과 같은 아시아산 호박에서 multiple structure 특징이 강하게 보여 아시아 외 지역에서 생 산되는 호박과 구분되고 있다.

PAH(polycyclic aromatic hydrocarbon)의 공기 중에 서의 형광스펙트럼의 파장이 naphthalene이 $\lambda_{\max }=333$ $\mathrm{nm}$, acenaphthene이 $\lambda_{\max }=333 \mathrm{~nm}$, fluorene이 $\lambda_{\max }=$ $313 \mathrm{~nm}$, phenanthrene이 $\lambda_{\max }=360 \mathrm{~nm}$ 으로 보고되었다. ${ }^{5}$ 또한, cyclohexane용매 안에서의 형광스펙트럼의 파장 도 보고되었는데, naphthalene이 $\lambda_{\max }=322 \mathrm{~nm}$, pyrene 이 $\lambda_{\max }=381 \mathrm{~nm}$, anthracene이 $\lambda_{\max }=397 \mathrm{~nm}, 9,10$ - diphenylanthracene 이 $\lambda_{\max }=302 \mathrm{~nm}, 9,10$-bis(phenylethynyl)anthracene이 $\lambda_{\max }=467 \mathrm{~nm}$ 였으며, ${ }^{6}$ ethanol에서 perylene의 $\lambda_{\max }=443 \mathrm{~nm}$ 였다. ${ }^{3}$ 또한, $300{ }^{\circ} \mathrm{C}$ 에서의 형 광스펙트럼도 공기 중의 값과 비교했을 때 약 $10 \mathrm{~nm}$ 정도 장파장으로 이동하는 정도로 유사한 결과를 보 이고 있다. ${ }^{7}$ 따라서, 실제 호박을 구성하는 aromatic 분자는 perylene이상의 conjugation을 하고 있다고 판 단된다. Dominican 호박의 경우 $\lambda_{\max }$ (yellow amber)= $433 \mathrm{~nm}, \lambda_{\max }$ (blue amber) $=475 \mathrm{~nm}$ 라고 보고되고 있어 우리의 결과와 유사한 값을 보이고 있다. ${ }^{3}$ Matuszewska 등은 Baltic 호박의 ethanol, methylene chloride 추출물에 서 발광을 나타내는 물질로 acenaphthene, naphthalene, phenanthrene, anthracene, fluorene 등을 보고하였는데, ${ }^{8}$ 이들 물질이 나타내는 형광과 고체상태 호박의 형광이 크게 차이가 나는 것으로 보아 추출물의 성분으로서 고체상태의 형광을 설명하기 어려운 것으로 보인다.

\subsection{UV 열화에 따른 형광 변화}

UV 열화 시 Colombian 호박을 제외하고 열화가 진 행되면서 intensity가 크게 감소하였다(Fig. 2). 최대 emission 파장도 Baltic 호박의 경우 $420 \mathrm{~nm}$ 에서 560 $\mathrm{nm}$ 로 장파장으로 이동하였다. 단파장에서의 emission 의 세기는 감소한 대신 장파장에서의 emission의 세기 가 증가하였다. excitation스펙트럼도 유사한 경향을 보였다. 세기가 전체적인 감소를 보이는 대신 파장대 별로 증가와 감소가 있었다는 것은 형광을 나타내는 물질의 전체적인 감소보다는 형광 성분이 2 종류 이 상이며 그 성분들의 구성비가 변하였음을 의미한다. 예를 들어, 방향성 고리(aromatic ring)의 파괴가 일어 나면서 그 중의 일부가 축합(condensation)을 일으켜 방향성이 더 높은 물질을 생성했을 수 있다. Colombian 호박의 형광은 처음부터 미약하며, 열화가 되면서 약 간 형광이 증가하였는데, 실제로, 형광사진에서도 파 

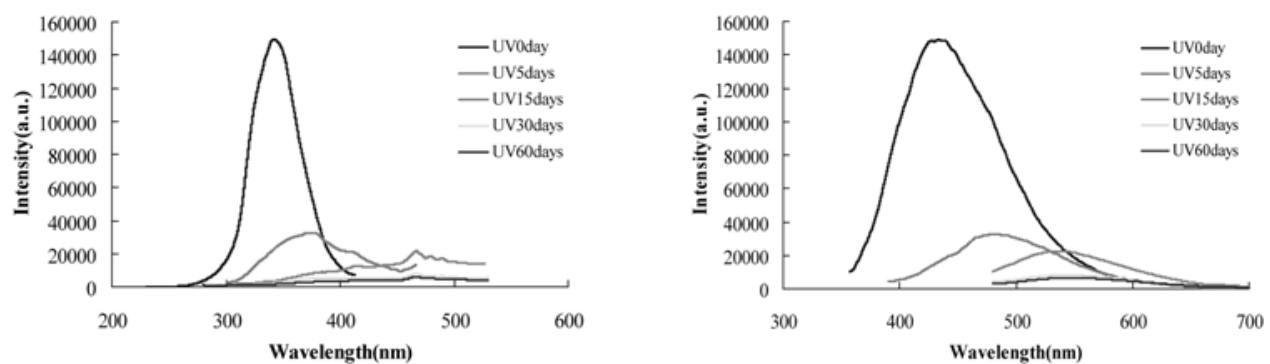

(a)
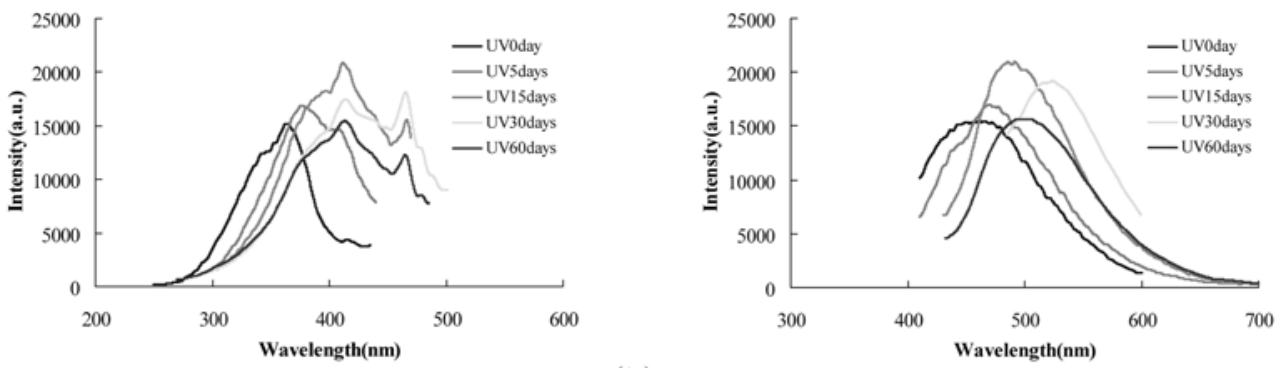

(b)
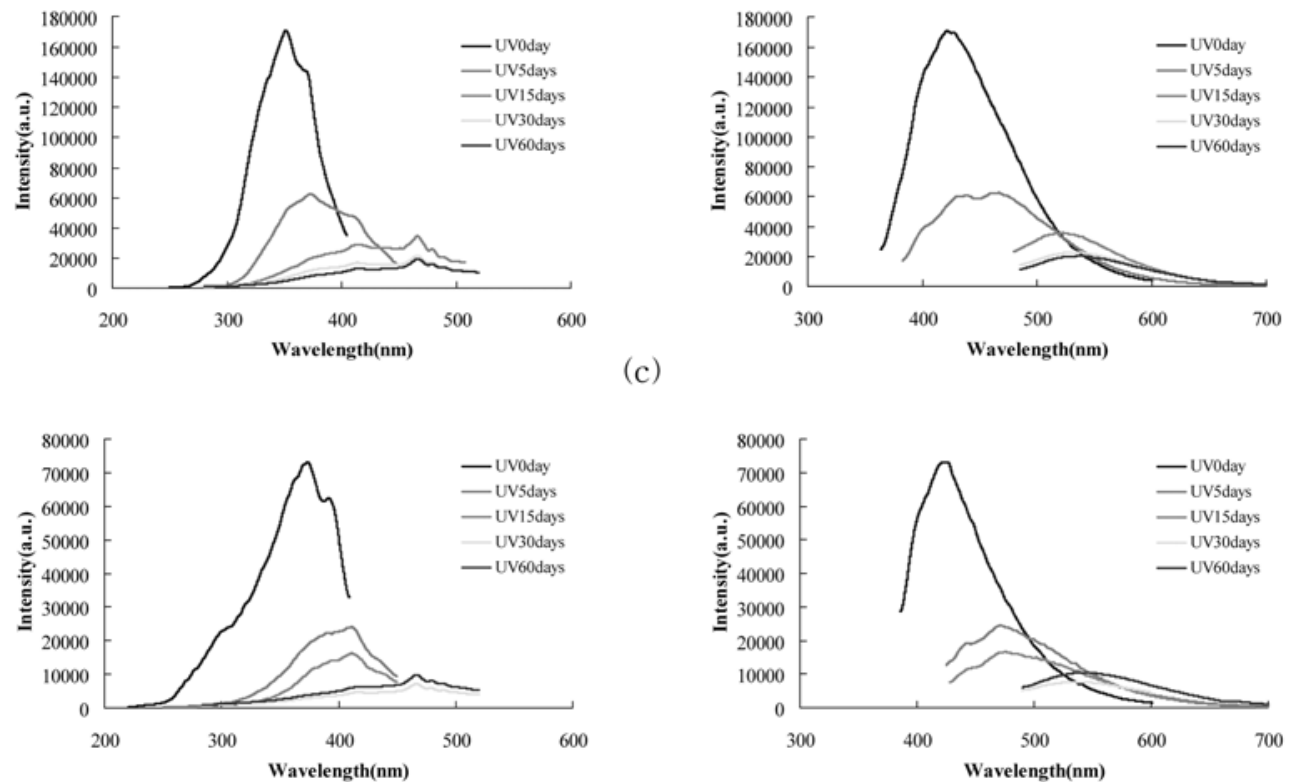

(d)

Fig. 2. Excitation (left) and emission spectra (right) of ambers after UV irradiation of $340 \mathrm{~nm}$ for $0,5,15,30,60$ days. (a) Baltic, (b) Colombian, (c) Dominican and (d) Fushun amber.

단면과 풍화면의 형광차이가 크지 않았다(Table 2). Colombian 호박의 경우 다른 호박과 마찬가지로 열화 와 함께 스펙트럼의 파장이 증가하였으나, emission 과 excitation 세기가 열화가 진행되면서 오히려 증가 하였다(Fig. 2(b)). 또한, excitation스펙트럼의 경우 하 부구조(sub-structure)도 두드러졌음을 볼 수 있다. subpeak의 위치 변화가 거의 없는 대신 열화와 함께 상대 적인 세기가 달라지는 것도 흥미롭다. Colombian 호 박도 다양한 방향족 고리를 가지는 물질들로 구성되 어 있으며 열화정도에 따라 그 것들이 발하는 형광의 
상대적인 세기가 변한다는 것을 알 수 있기 때문이다. 이러한 특성은 excitation 또는 emission스펙트럼 구성 peak의 상대적인 세기로부터 호박의 열화정도를 예측 하는데 활용될 수 있다. 동일산지의 호박에 대해 열화 에 따른 구성 peak변화가 유사함을 확인하는 경우 실

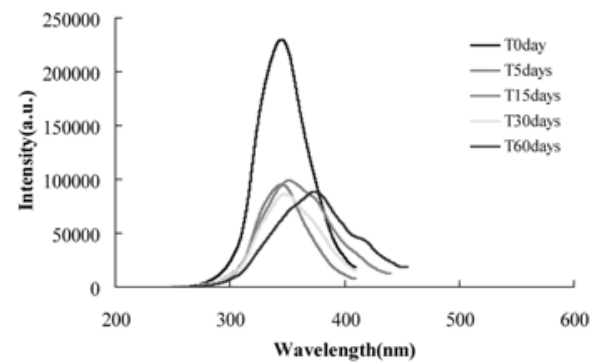

(a)

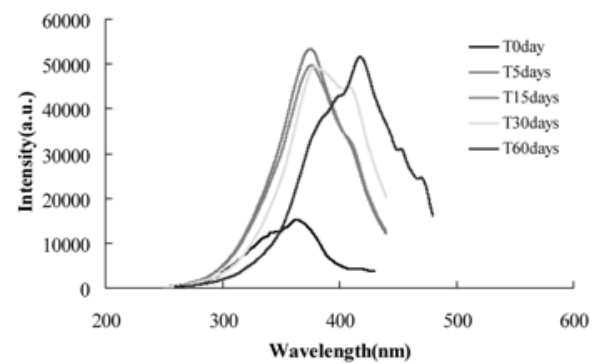

(b)

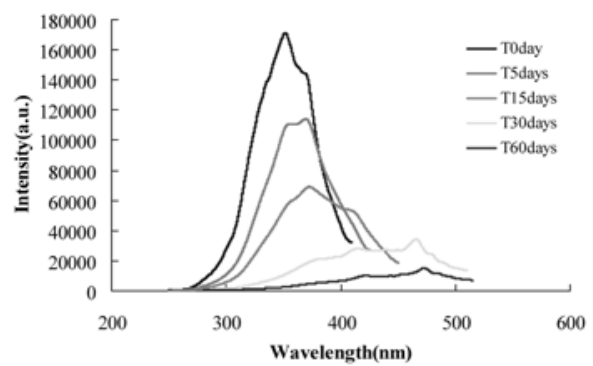

(c)

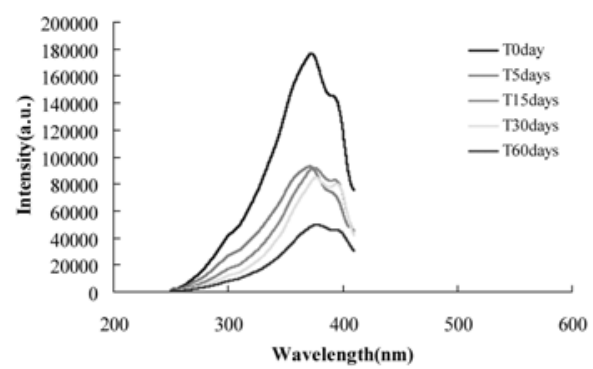

(d)

a)
제 열화정도 파악이 가능할 것으로 사료된다. 다른 호 박과 달리 형광의 세기가 열화와 함께 증가하는 것은 $\mathrm{py} / \mathrm{GC} / \mathrm{MS}$ 분석에서 비공액(nonconjugated) 이중결합을 가지는 분자가 다량 검출된 점으로부터 ${ }^{9} \mathrm{UV}$ 에 의한 이중결합의 공액화(conjugation) 반응이 활발하게 일어
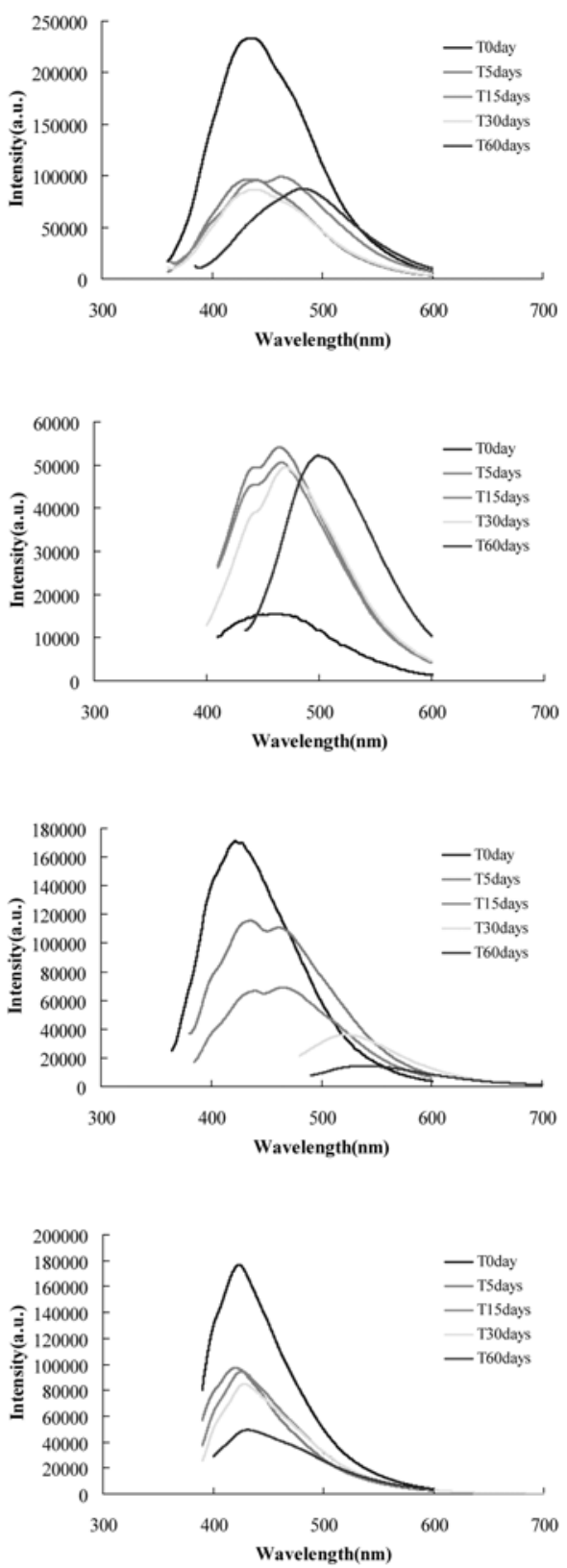

Fig. 3. Excitation (left) and emission spectra (right) of ambers after thermal aging for $0,5,15,30,60$ days. (a) Baltic, (b) Colombian, (c) Dominican and (d) Fushun amber. 
나 방향족 고리를 가지는 물질의 생성량이 파괴량보 다 훨씬 많기 때문으로 설명할 수 있다. 이는 alkyl benzene, alkyl naphthalene, alkyl tetralin 등이 여러 가 지 sesquiterpenoid나 diterpenoid가 산화에 의해 고도 로 열화되면서 나타나는 변성산물이라고 보고한 R. Pereira 등의 연구에 의해 뒷받침되고 있다 ${ }^{10}$. 즉, 변성 이 덜 된 Colombian 호박이 UV의 영향에 의해 변성 이 촉진되어 방항족 고리가 생성된 것으로 보인다. 하 지만, 모든 호박에서 결국에는 큰 방향족 고리도 파괴 가 되어 모든 방향족 고리가 사라지는 경향을 보이고 있다. 같은 위치에서 나타나는 구성 peak들도 파장대 가 조금씩 차이를 보이고 있는데 분자구조의 사소한 변화 또는 분자주변의 미세 환경이 약간씩 차이가 있 음을 반영하는 것으로 보인다.

우리가 호박의 간이 확인에 사용한 빛인 $365 \mathrm{~nm}$ 자외선에서의 excitation은 Baltic 호박의 경우 급격한 감소를 보여 60 일 후에는 거의 excitation이 일어나지 않으며(Fig. 2(a)), Dominican과 Fushun 호박의 경우에 도 시간이 지나면서 크게 감소한다(Fig. 2(c), (d)). 하 지만, Colombian 호박의 경우 30 일까지는 비슷한 세 기를 보이다가 60 일 후에야 약간의 감소를 보인다. 따 라서, 호박이 오랜 시간 빛에 노출되는 경우 Colombian 호박을 제외하고는 형광을 이용한 확인이 곤란할 것 으로 판단된다.

\section{3. 열 열화에 따른 형광 변화}

Fig. 3에 열 열화에 따른 형 광스펙트럼을 나타내었 다. 열 조건에서 열화가 진행되면서 나타나는 특징은 Dominican호박을 제외하고 형광의 파장변화가 적게 일어난다는 점이다. 특히 Fushun호박의 경우 60 일 열 화 후에도 파장변화가 거의 없다. 이는 산소가 없이 열만 존재하는 조건에서 방향성 고리(aromatic ring)를 가지는 성분의 변화가 별로 없다는 점을 말해 준다. 형광 세기도 산소나 UV 열화에 비하여 감소폭이 작 은 것으로 관찰되었는데, 호박의 열화가 열에 의해서 는 비교적 느리며, UV나 산소가 있을 때 촉진된다는 것을 말 해 준다. Colombian 호박에서는 열화초기에 다른 조건에서의 열화와 마찬가지로 형광의 증가가 있었는데, 열에 의해서 구성물질 간의 축합반응이 일 어났음을 알 수 있다. 아울러, 형광의 증가 폭이 UV 조건에서의 열화보다 큰 것으로 보아 열이 방향족 고 리(aromatic ring)의 생성에 중요한 역할을 하며, 산소 와 열이 공존하는 조건에서보다 증가폭이 큰 것은 산 소에 의한 방향성 고리의 파괴가 없기 때문이라 판단
된다.

\section{4. 열과 산소 열화에 따른 형광 변화}

산소와 열이 있는 조건에서 호박을 열화시켰을 때 Baltic, Dominican, Fushun 호박에서 5일이 경과했을 때부터 형광의 세기가 급격하게 감소하였다(Fig. 4). Baltic 호박의 경우 처음 값의 $8.8 \%$ (5일 후), $3.8 \%$ (15 일 후), $5.0 \%$ (30일 후), $1.7 \%$ (60일 후)로 감소하여, 60 일이 경과한 후에는 형광이 거의 관찰되지 않았다. 형광을 나타내던 방향성 고리(aromatic ring)가 산소와 열이 있는 조건에서 급격하게 파괴가 일어나는 것으 로 보인다. 열만 있는 조건에 비하여 급격한 변화를 보인 것은 산소가 호박의 열화에 큰 영향을 미친다는 것을 의미한다. G. Pastorelli 등이 공기 중 $70{ }^{\circ} \mathrm{C}$ 에서 70 일 동안 열화를 시켰을 때 시료 표면에서 $0.25 \mathrm{~mm}$ 이내에서 $\mathrm{C}=\mathrm{O}$ 결합의 큰 증가가 있음을 확인했는데, 이중결합이 산소와 반응을 일으키면서 그러한 현상이 발생하는 것으로 해석하였다. ${ }^{11}$ 또한, 호박을 열화시키 면서 IR과 산소농도를 측정하여 열화에 있어 산소의 역할을 증명하였고, Baltic 호박의 열화가 산화에 의한 라디칼 연쇄반응임을 제안하였다. ${ }^{2}$ 따라서, 산소가 있 는 조건에서 형광의 감소가 더욱 급격한 것도 산소에 의한 이중결합의 파괴로 설명할 수 있을 것으로 보인 다. 한편, Colombian 호박은 5일 경과했을 때 형광의 급격한 증가가 일어났으며, 시간이 지나면서 완만하게 감소하는 양상을 보였다. 이는 UV열화와 비슷한 결과 로 방향성 고리(aromatic ring)의 파괴보다는 이중결합 간의 가교결합으로 방향성 고리의 생성이 더 활발하 기 때문이라고 판단된다. 모든 호박에서 시간이 지나 면서 단파장의 흡수와 형광이 줄어들면서 장파장 쪽 으로 이동하는 것도 관찰되었다. 장파장의 빛을 흡수 하는 방향성(aromaticity)이 큰 분자가 더 안정하기 때 문에 단파장의 세기가 급격하게 줄어드는 동안 장파 장의 세기가 유지되는 것으로 보인다.

\section{5. 자연 풍화시료의 형광}

Fig. 5는 호박원석의 풍화된 표면의 형광스펙트럼이 다. 원석 호박시료는 덩어리로 되어 있으며 표면은 풍 화에 의해 내부와 전혀 다른 모습을 보이고 있다 (Table 1). 풍화에 따라 손상된 호박원석 표면의 형광 을 관찰하여 그와 비슷한 풍화환경을 따를 가능성이 있는 호박유물의 형광을 예측하고자 하였다. 전체적으 로 손상되지 않은 내부 시료와 비교했을 때 표면의 형광세기가 감소하는 것으로 나타났으며, 이는 

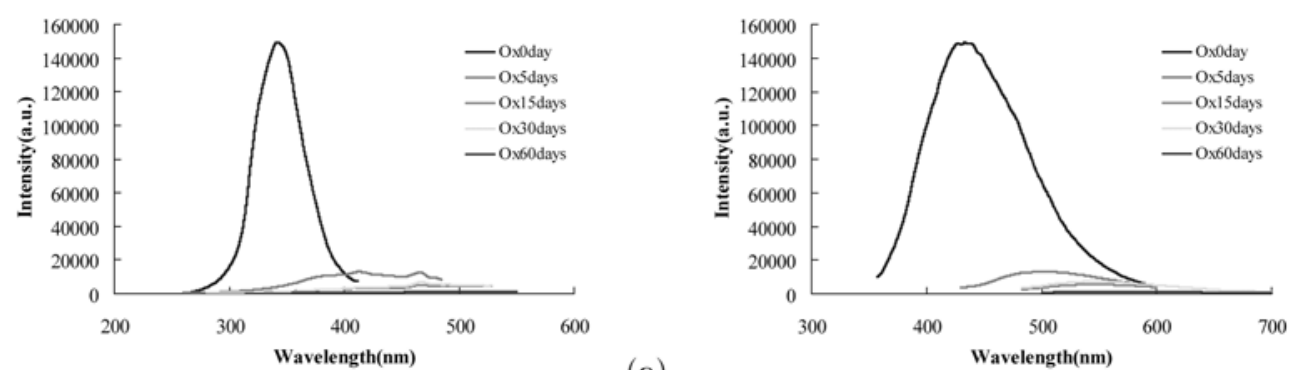

(a)
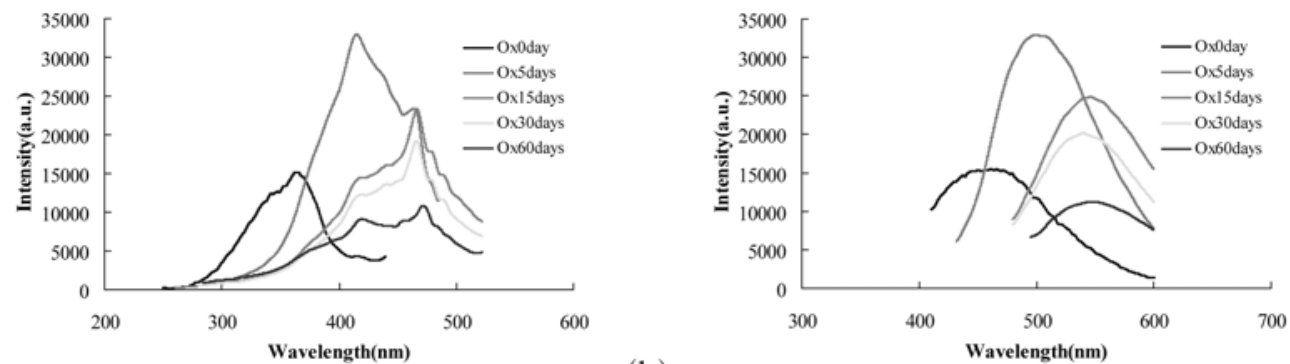

(b)
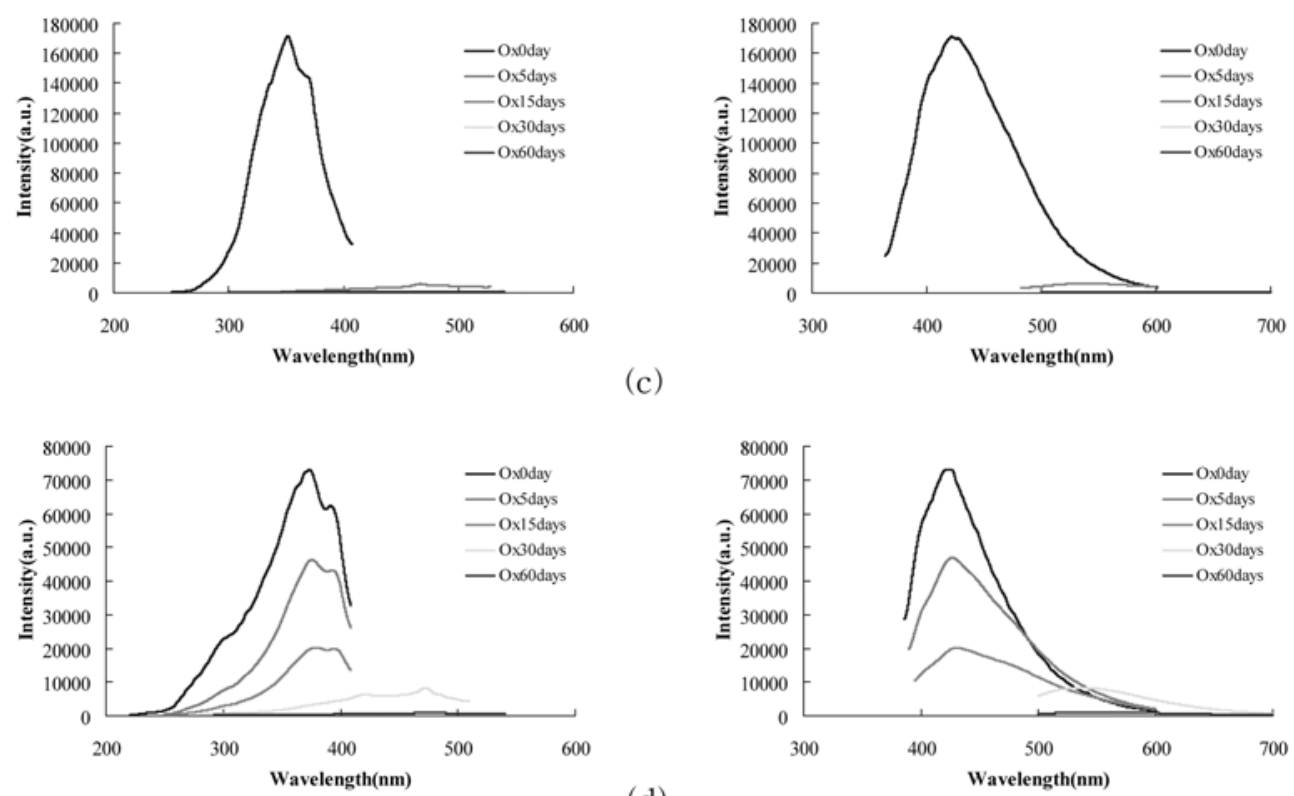

(c)

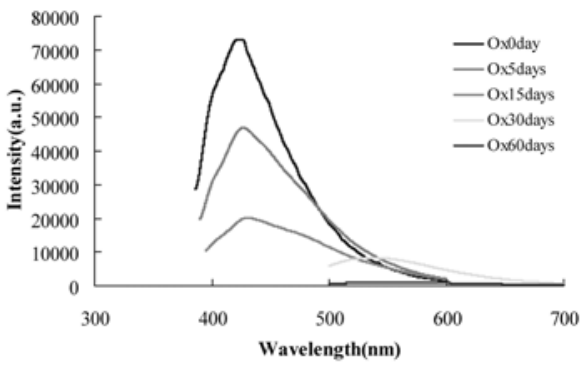

(d)

Fig. 4. Excitation (left) and emission spectra (right) of ambers after thermal aging with oxygen for 0, 5, 15, 30, 60 days. (a) Baltic, (b) Colombian, (c) Dominican and (d) Fushun amber.

$\mathrm{UV}(\lambda=365 \mathrm{~nm})$ 를 조사했을 때 표면의 형광이 거의 관찰이 되지 않은 것과 일치하고 있다(Table 2). 다만, Colombian 호박의 경우 형광의 세기는 작았으나, 풍 화가 일어난 표면이 오히려 내부보다 형광의 세기가 컸다. 이는 우리의 열화실험 결과와도 일치하는 결과
이다. 인공열화 조건에서 얻은 결과와 비교했을 때 Baltic 호박은 UV 또는 산소 열화와 유사하고, Colombian호박은 열, UV, 산소 열화와, Dominican호 박은 산소열화와, Fushun호박은 열 및 산소 열화와 유 사하다고 할 수 있다. 

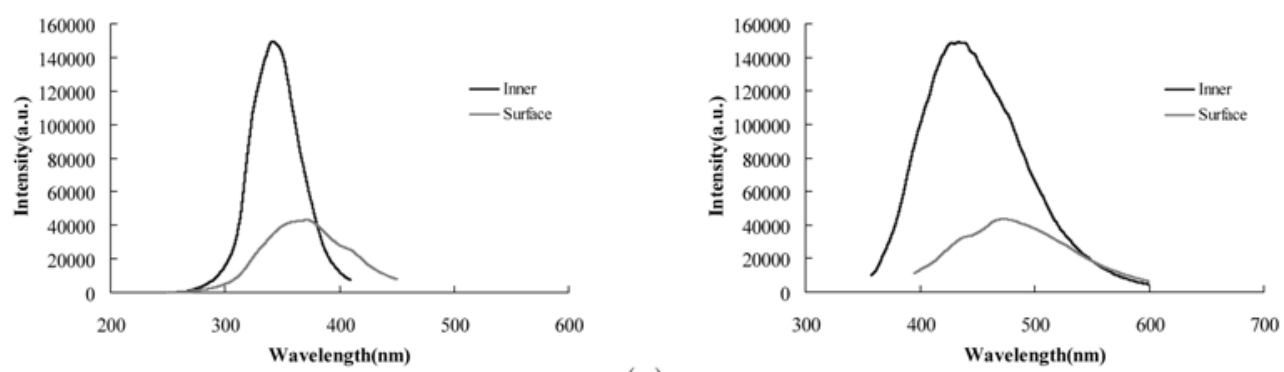

(a)
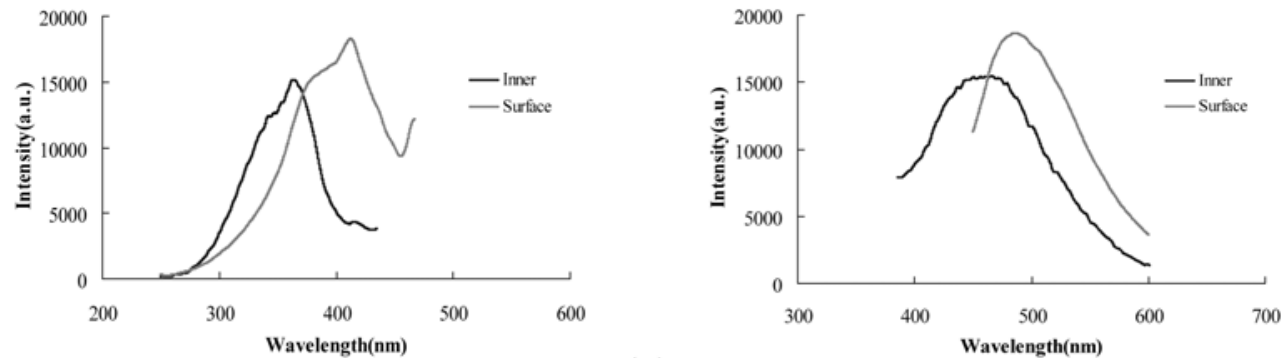

(b)
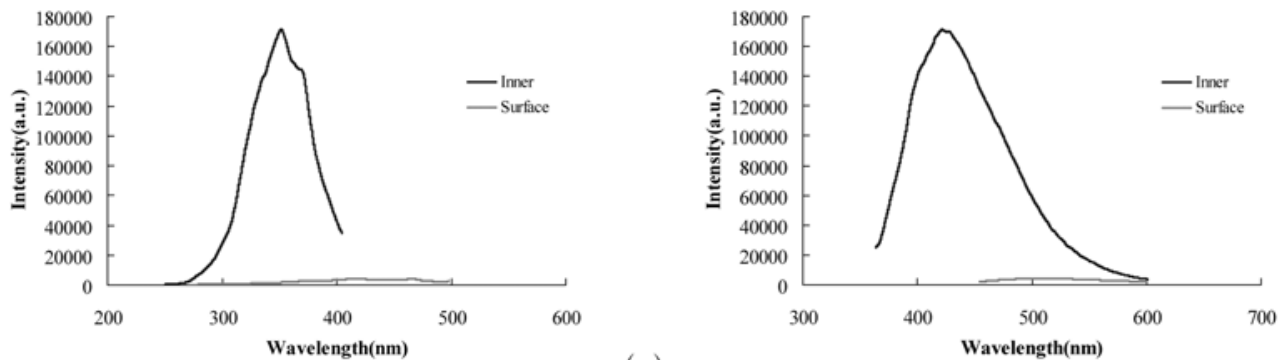

(c)
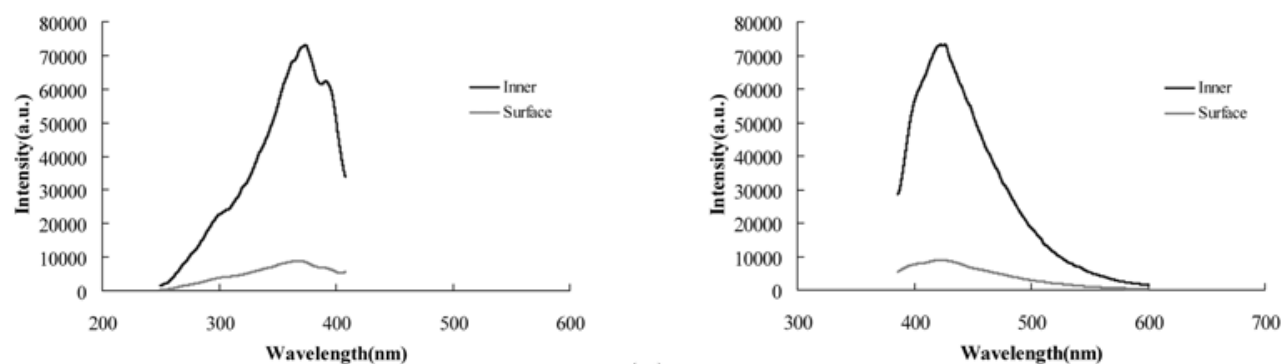

(d)

Fig. 5. Excitation (left) and emission spectra (right) of inner part and surface of naturally aged ambers. (a) Baltic, (b) Colombian, (c) Dominican and (d) Fushun amber.

\section{4. 결 론}

1. 열화 전 호박의 형광세기는 Dominican, Baltic, Fushun, Colombian 호박 순이었으며, 파장범위는 350 550 nm로 노랑, 초록, 파랑, 남색에 해당하였다.
2. 열화에 따른 호박의 형광변화를 관찰했을 때 Colombian 호박을 제외하고 열화가 진행됨에 따라 형 광의 세기가 감소하였으며, 특히 산소조건 하에서 급 격하게 감소하였다. 반면, Colombian 호박의 경우 열 화와 함께 일정시간 동안 형광의 증가가 관찰되었다. 
3. 또한, 열화가 진행되면서 대체적으로 형광이 장 파장으로 이동하였다. 열에 의한 열화의 경우에는 파 장의 변화가 비교적 적고 세기 감소가 주로 나타나 성분변화가 가장 적은 열화임을 알 수 있었다.

4. 열화를 통해 호박에서 형광을 나타내는 물질들이 다양할 수 있으며, 각 파장에서의 형광세기를 비교함 으로써 호박의 열화정도를 가늠하는 것이 가능할 것 으로 보인다.

5. 자연상태에서 풍화된 시료의 경우도 신선한 호박 과 비교했을 때 형광의 세기가 크게 감소한 것을 알 수 있었으며, 풍화 상태에서는 형광의 세기가 육안으 로 식별하기에 곤란할 정도로 작았다.

6. 따라서, 호박유물 조사에서 호박의 확인을 형광 관찰에만 의존하기는 어려운 것으로 판단되며, 풍화문 관찰, IR 조사 등 다양한 비파괴적인 조사법을 도입할 필요가 있다.

\section{감사의 글}

본 연구는 국립문화재연구소에서 지원한 문화유산 기본연구(R\&D) 중 문화재 과학적 복원 연구의 일환 으로 진행되었다.

\section{참고문헌}

1. L. Carlsen, A. Feldthus, T. Klarskov and A. Shedrin- sky, J. Anal. Appl. Pyrolysis, 43, 71-81 (1997).

2. M. Villanueva-García, A. Martínez-Richa and J. Robles, ARKIVOC, 449-458 (2005).

3. V. Bellani, E. Giulotto, L. Linati and D. Sacchi, $J$. Appl. Phys., 97, 016101 (2005).

4. S. Chouten, M. Woltering, W. I. C. Rijpstra, A. Sluijs, H. Brinkhuis and J. S. S. Damsté, Earth Planet. Sci. Lett., 258, 581-592 (2007).

5. I. Litani-Barzilai, V. Bulatov, V. V. Gridin and I. Schechter, Anal. Chim. Acta, 501, 151-156 (2004).

6. H. Du, R.-C. A. Fuh, J. Li, L. A. Corkan and J. S. Lindsey, Photochem. Photobiol., 68, 141-142 (1998).

7. R. Sun, N. Zobel, Y. Neubauer, C. C. Chavez and F. Behrent, Opt. Laser. Eng., 48, 1231-1237 (2010).

8. A. Matuszewska and M. Czaja, Talanta, 56(6), 10491059 (2002).

9. J. Park and Y. Lim, Anal. Sci. Technol., 24(4), 256-265 (2011).

10. R. Pereira, I. de S. Carvalho, B. R. T. Simoneit and D. de A. Azevedo, Org. Geochem., 40, 863-875 (2009).

11. G. Pastorelli, J. Richter and Y. Shashoua, Spectrochim. Acta $A$, in press.

12. G. Pastorelli, J. Cult. Herit., 12, 164-168 (2011). 